\title{
Irreplaceable Images of Isolated B Cell NHL of the Skin
}

\section{Pierpaolo Di Micco*}

UOC Medicina, Fatebenefratelli Hospital of Naples, Italy

These images report the unusual diagnosis of isolated B cell NHL CD 19 positive localized in the skin of a patient with localized prurigo and erythema. PET-CT did not reveal any type of further localization of the disease.

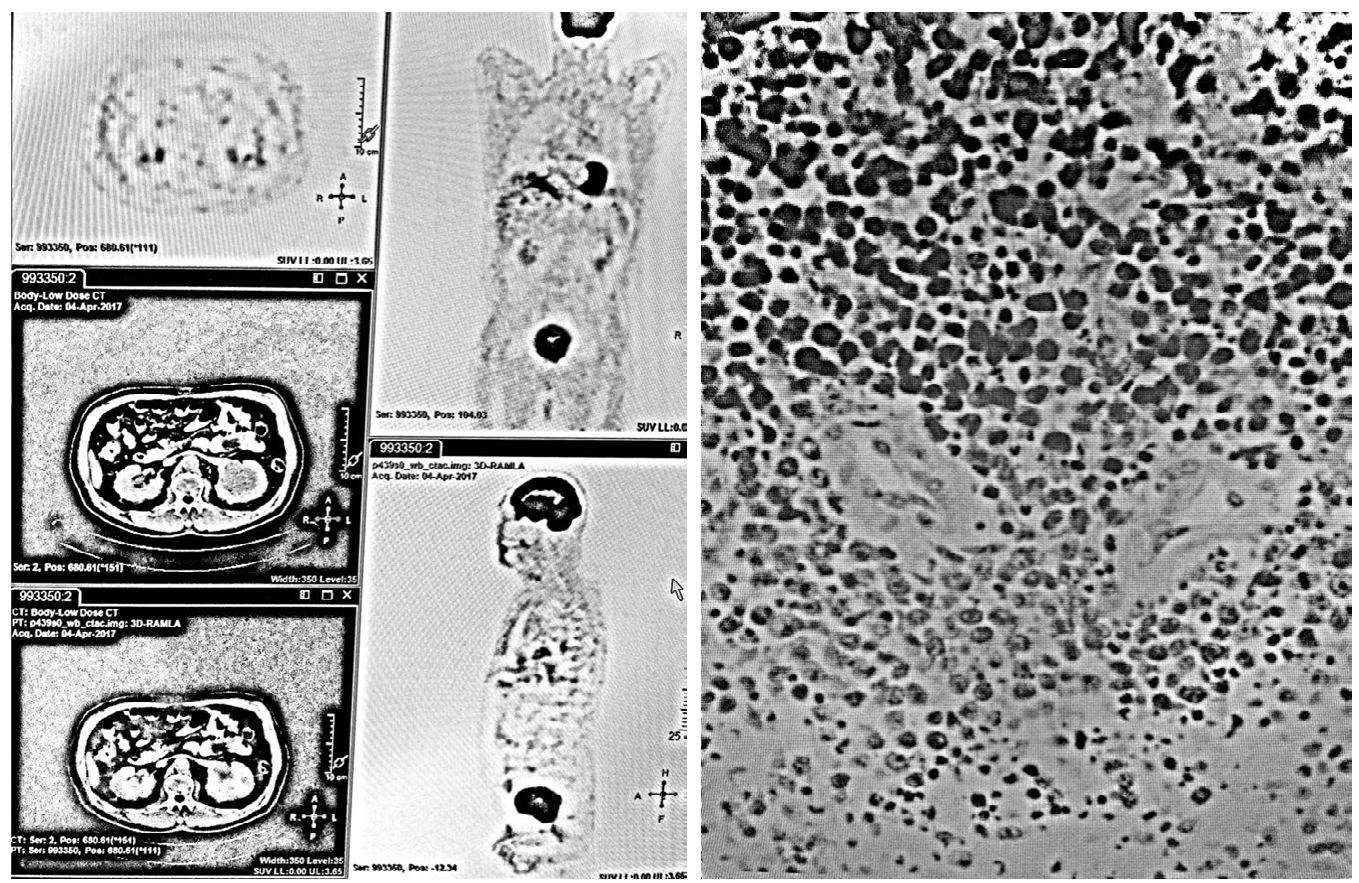

Figure 1: Solitary NHL B lymphoma of the skin.

*Corresponding author: Di Micco P, UOC Medicina, Fatebenefratelli Hospital of Naples, Italy, Tel: 393398 078146; E-mail: pdimicco@libero.it

Received December 28, 2018; Accepted December 29, 2018; Published December 31, 2018

Citation: Di Micco P (2018) Irreplaceable Images of Isolated B Cell NHL of the Skin. J Blood Lymph 8: i105. doi: 10.4172/2165-7831.1000i105

Copyright: ๑ 2018 Di Micco P. This is an open-access article distributed under the terms of the Creative Commons Attribution License, which permits unrestricted use, distribution, and reproduction in any medium, provided the original author and source are credited. 